\title{
Grundtvig og den første folkehøjskoles mænd.
}

\author{
Af Roar Skovmand.
}

\section{Grundtvigs Skamlingstale 1844 .}

Den første folkehøjskole, der blev grundlagt i Danmark, var ikke en frugt af N.F.S. Grundtvigs tanke om en folkelig højskole i Sorø, men han lyste den i kuld og køn i sin tale på Skamlingsbankemødet den 4. juli 1844 .

Når vi nu læser denne tale ${ }^{1}$ ), virker den noget floromvundet, men vi har Grundtvigs egne ord for at mødet med de mange tusinde landsmænd på Nordslesvigs højeste punkt den friske sommerdag virkede forløsende på ham og gav hans ord vinger - de har nok befriet ham fra hans tunge manuskript.

Den tyveårige bondeknøs Niels Jokum Termansen havde før solopgang begivet sig til fods fra sit hjem i Vejen for at være med til mødet, hvor nogle af Danmarks mest veltalende mænd skulle føre ordet. Han hørte på Laurids Skau, på Carl Ploug og Orla Lehmann, men det var Grundtvigs tale, der gjorde stærkest indtryk på ham. Mange år efter sagde han, at han huskede den som igår: »Ikke et eneste øjeblik vendte jeg øjet og tanken fra ham under det fem kvarter lange, men som det forekom mig, kun lige så mange minutter lange foredrag, og jeg synes endnu, jeg ser og hører Dannebrog vifte over hans hoved $\mathrm{i}$ den friske vestenvind $\left.\ll^{2}\right)$.

Her holder Grundtvig sin første og største tale om folkehøjskolen, her står han første gang overfor en reel plan om en virkeliggørelse af tanker, der var nær beslægtet med hans, og her giver han håndslag på, at han vil støtte den første folkehøjskole.

Når Grundtvig kunne holde højskoletale på dette møde, skyldtes det, at nordslesvigske bønder året før havde stiftet Den slesvigske

1) N. F. S. Grundtvig: Skov-Hornets Klang mellem Skamlings-Bankerne, Kbh. 1844 .

2) Jakob Petersen: Skamlingsbanken, Kbh., 1943, s. $102 \mathrm{f}$. 
Forening, der med støtte fra nationalliberale kredse i København havde købt en gård i Rødding til højskole. Professor Chr. Flor i Kiel var valgt til skolens formand, den unge teologiske kandidat Johan Wegener havde sagt ja til at blive forstander, og få uger før Skamlingmødet forelå kongens tilladelse til skolens oprettelse.

Der er et suk i Grundtvigs tale, et suk over, at »den danske højskole ej hævede sig først i hjertet af Sjælland, i det dejlige Sorø, hvor pladsen er afstukket af forsynet selv, hvor alle midlerne er i overflødighed tilrede, og hvor altså kun lysten eller modet eller kræfterne fattes«, men han trøster sig med, at Danmarks skole nu bygges, hvor Danmarks rige og Danmarks kirke blev til. Han ser, at skal det levende Dannevirke, som ene kan modstå tyskernes angreb, holde stand, da er åbenbart en »højskole« nødvendig, ingen »latinsk højskole« som universitetets, men en »dansk højskole«, hvor Nordens ånd på modersmålet kan sætte tysken på plads. Det er et »kæmpeskridt«, siger Grundtvig, slesvigerne nu har gjort ved at ville rejse en sådan skole, og når han har taget ordet, er det for at ønske dem og Danmark, Nordens ånd og menneskeslægten til lykke dermed. En sådan »dansk højskole«, siger Grundtvig, »var alt i mange år min sødeste drøm og manglen deraf mit bitreste savn, fordi det er mig soleklart, at rejser sig ikke brat en sådan, en virkelig, åndfuld dansk højskole, og står fast, da er det, i henseende til folket, omsonst og forgæves, alt hvad vi har stridt og lidt, skjaldret og sunget, sagt og skrevet til modersmålets ære...«

Til sin lykønskning føjer Grundtvig en tilskyndelse til at gøre værket færdigt. I skal, siger han, rejse en højskole i jeres midte, der er jeres fortid og Danmark værdig, »en højskole, hvis danskhed man kan se hundrede mile borte, og hvis budskab kan høres over al verden «. Det må ikke forknytte jer, at der i hele kongeriget ikke findes mønster eller mage dertil - ligesom i gamle dage må det være slesvigernes opgave at danne mønster for os i kongeriget.

Til slut lover Grundtvig, at hvad han, der med flid har dyrket modersmålet og sat sig ind $\mathrm{i}$ »den nordiske kæmpeånds billedsprog og tankegang « kan bidrage til, at den nye danske højskole kan blive en »Mimers brønd «, »hvortil konger ride for at søge råd«, det skal han gøre - og det er derfor, han har taget ordet her.

Det, der greb tilhørerne på Skamling stærkest, var nok at Grundtvig til slut fortalte sagnet om Folke, der lovede kong Vermund, at før han ville rømme marken for Danmarks fjender, ville han tømme 
det bæger, han nu havde fået af kongen, med sit eget blod! Det, der gav talen sin baggrund i øjeblikket, var den torden $\mathrm{i}$ syd, der truede med dobbelt kamp: militært og folkeligt. Det, der giver talen værdi udover øjeblikket er, at vel blev den militære kamp tabt ved Dannevirke og Dybbøl, men den folkelige blev virkelig vundet, og heri havde den danske folkehøjskole, som Grundtvig bød velkommen på Skamling, sin del.

\section{Christian Flor og Grundtvig.}

Den mand, der stod bagved Danmarks første folkehøjskole, var dog ikke Grundtvig selv, men en af hans selvstændigste disciple, den danske lektor ved Universitetet i Kiel, professor Christian Flor. Da Grundtvig i efteråret I 860 lå alvorligt syg, skrev Flor, som på det tidspunkt opholdt sig hos sin søn i Sverige, til Sofus Høgsbro i Rødding, at nu fik han nok ikke mere Grundtvig at se, og så tilføjer han disse ond, der virker som en bekendelse: »At dette går mig til hjertet, véd De; thi ham vil jeg komme til at savne, uagtet jeg kun sjælden talte med ham, eller følte trang til at tale med ham. Men jeg vidste dog, hvor han var at finde, hvis blik gik i samme retning som mit, kun at hans øje var langt skarpere og sikrere end mit; derfor var jeg rolig, om jeg end på min vej blev så langt bag ham, at jeg knap øjnede, hvor han var. Når da en sådan fører og anfører med ét forsvinder, og vi er ganske overladt til os selv, da ængstes vi vel tit $\ll^{3}$ ).

Mellem linjerne siges der i dette brev, at Grundtvig ikke har stået Flor og Rødding så nær, som Flor havde håbet, men at Grundtvig alligevel var som den skystøtte, der angav målet og vejen.

Det havde han været for Flor længe inden højskolen kom på tale. I I 837 skrev Flor til en ven, at han var den eneste - bortset fra Grundtvig selv - der havde forstået Grundtvigs store »Nordens Mythologi« fra $1832^{4}$ ); han havde ene af alle danske anmeldt værket, men fik ikke sin afhandling, der er en hel lille bog, trykt før i $183^{5}$ ). Flor læste forinden sin afhandling op for Grundtvig, som sagde til ham, at han havde truffet hans mening på en $\left.\operatorname{prik}^{4}\right)$. Hele

3) Højskolens Ungdomstid i Breve, v. Roar Skovmand, Kbh. I96o, I, nr. 26 r.

4) Brev til Pet. Chr. Koch $3 / 10$ 1837, se P. Lauridsen: Da Sønderjylland vaagnede $\mathrm{I}^{2}$, s. $106 \mathrm{f}$.

5) Brage og Idun, udg. af Fr. Barfod, I, Kbh., I 839, s. I 76-230. 
den dybtgående indflydelse, som Flor havde haft på den danske nationalitetskamp i Nordslesvig i dens første fase, var sket under inspiration af Grundtvig. Det var således helt i Grundtvigs ånd, når Flor hævdede, at »når et folk mister sit modersmål, må nødvendigvis hjertet hos de enkelte blive koldt og egoistisk, og ingen folkeånd vil kunne finde bolig til ophold hos $\left.\operatorname{dem} \ll^{6}\right)$. Når danskhedens førende organ i Nordslesvig fik navnet »Dannevirke« i 1838, var det en opkaldelse efter Grundtvigs tidsskrift af samme navn, som var udkommet en snes år tidligere ${ }^{7}$ ). I den læsebog eller håndbog i den danske litteratur, som Flor udgav første gang 183 I, fik Oehlenschläger 65 sider, Grundtvig 25 - i dens syvende udgave, som kom omkring 40 år senere, fik Grundtvig 42, Oehlenschläger kun 35 sider $\left.^{8}\right)$. Grundtvigs højskoletanker synes Flor dog ikke i i 83oerne at have været særlig optaget af - de omtales således slet ikke i hans anmeldelse af Nordens Mythologi.

Da der omkring nytår I84I blev slået til lyd for »højere bondeskoler« både fra dansk og tysk side, gik de flestes tanker i retning af realskolen, men Flor tog klart afstand herfra. I et brev til »Dannevirkes« redaktør Peter Christian Koch i juni i 84I gav han besked: »Den hele historie med realskolen må jeg vel blive udenfor, så gerne jeg end havde min finger deri. Thi hvad jeg anser for menigmands åndelige og politiske frelse, får jeg næppe nogen til at begribe, det er nemlig netop den samme »højskole-idé«, som Grundtvig har flere gange skrevet om og tilsidst ifjor udgivet en lille piece om: »Dansk Høiskole i Sorø $\left.\ll^{9}\right)$, men som naturligvis intet menneske har forstået et ord af «. Flor fortæller videre, at han har skrevet en artikel om Grundtvigs skrift, men ingen af de førende københavnske blade har villet optage den - de svarede, at den stred mod deres grundsætninger ${ }^{10}$ ). Da planerne i januar $\mathrm{I} 84^{2}$ fik fastere form, udtrykte »Fædrelandet« i København sin betænkelighed, der grundede sig på at nogle af ophavsmændene tilhørte det grundtvigske parti. Derpå fulgte følgende salve: »Dettes tilhængere er - det være sagt med al

6) P. Lauridsen: Da Sønderjylland vaagnede I², s. 4 I, Jfr. Højskolens Ungdomstid II, Rødding nr. 388.

7) Om Grundtvigs egen mere forbeholdne indstilling se Troels Fink: Grundtvig og Sønderjylland, Jyske Samlinger Ny Rk. I, I950, s. 59 ff.

8) Th. Roust: Chr. Flor, I923, s. 33 .

9) N. F. S. Grundtvig: Bøn og Begreb om en Dansk Høi-Skole i Soer, Kbh. I840.

10) P. Lauridsen: Da Sønderjyll. vaagnede IV, s. I98, jfr. Højskolens Ungdomstid I, nr. 5 . 
mulig agtelse for dets geniale overhoved - vistnok i det hele mindre godt skikkede til at indrette undervisningsanstalter; i det mindste er Grundtvigs egne ideer herom så uklare, at der ikke hører stor dristighed til at erklære dem for uigennemførlige $\left.\ll^{11}\right)$.

Således skrev »Fædrelandet « $\mathrm{i}$ januar $\mathrm{i} 842$, men inden årets udgang havde de Nationalliberale, som stod bagved dette blad, skiftet holdning. Baggrunden herfor var, at Hiort Lorenzen, den stænderdeputerede for Sønderborg, den I I. november I 842 havde talt dansk i stændersalen og »vedblev at tale dansk«. Denne handling, som Flor havde givet stødet til, manede til sammenhold hos alle danske, og Lorenzen blev hyldet både af Grundtvig og af de nationalliberale ledere. I maj I843 skabte disse med Grundtvigs arge modstander, professor $H$. N. Clausen, i spidsen en fond til oprettelse af danske undervisningsanstalter i Nordslesvig, og kort efter stiftede nordslesvigske bønder Den slesvigske Forening med samme formål. Det lykkedes Flor at overbevise til alle sider om, at det var nødvendigt at rejse en højskole: Den I I. november I 843, på årsdagen for Hiort Lorenzens tale, skrev han triumferende til Koch, at det nu var lykkedes ham at få både de gamle og de unge liberale til at »overlade os overkommandoen i nationalkampen og at tro på vor overvisdom og overudholdenhed $\ll^{12}$ ).

Flor blev den selvskrevne formand for Rødding Højskoles direktion. Som den kloge general han var, undgik han at få udprægede grundtvigianere med i ledelsen, men derfor opgav han ikke den grundtvigske retningslinje. I et brev til Koch kort efter nytår I844 skrev han, at Nordslesvigs selvstændighed kun kan skabes »ved en anstalt som højskolen eller noget sligt, som kan meddele åndelig lys og varme $\left.\ll^{13}\right)$. Men i programmet fra juni I 844 balancerede Flor mellem grundtvigianisme og rationalisme, når han udtalte, at målet var at meddele bonde og borger »sådanne kundskaber og færdigheder, som kan være til nytte og behag, ikke så meget med hensyn til hans særegne næringsvej og bedrift som med hensyn til hans stilling som landets søn og borger. Anstalten skulle altså have en velgørende indflydelse såvel på hans huslige og private som på hans offentlige og borgerlige liv $\left.\ll^{14}\right)$. Da Flor to år senere udsendte skolens

11) Fædrelandet $27 / 1$ r 842 .

12) P. Lauridsen: Da Sønderjyll. vaagnede VI, s. 8o. Højskolens Ungdomstid I, nr. 15.

13) P. Lauridsen VI, s. 91. Højskolens Ungdomstid I, nr. 25.

14) H. Rosendal: Nogle Bidrag til Rødding Højskoles Hist., Kolding I894, s. 27 f. 
første årsberetning, klang tonen stærkere i grundtvigsk dur: 》Det vigtigste ved undervisningen på vor højskole er ikke de positive kundskaber og færdigheder, som vi søger at bibringe eleverne, men snarere det hele åndelige liv, som bliver vakt og næret hos dem, så at deres forstand bliver skarpere, deres dømmekraft modnere, deres hjerte åbnere og ædlere, at der vækkes hos dem sans for orden, skønhed og et smagfuldt liv, at lyst til beskæftigelse kan træde i stedet for den sædvanlige dorskhedsvane, at deres sind og derved deres væsen kan blive frimodigere, deres følelse for kammeratskab og fædreland blive vakt, næret og styrket $\ll^{15}$ ).

Dette program, som blev Røddings, var så diplomatisk formet, at selv H.N. Clausen kunne gå med dertil, skønt han stærkt havde ønsket, at skolen ikke skulle »fjerne sig for meget fra karakteren af en læreanstalt $\left.\ll^{16}\right)$. Og dog var programmet grundtvigsk i sin kerne. - I sin litteraturhistorie har Vilhelm Andersen kaldt Rødding Нøjskole under Flors ledelse »højgrundtvigsk $\left.\ll^{17}\right)$. Udtrykket er rammende.

\section{De forste Roddinglorere og Grundtvig.}

Det var Chr. Flor, som havde udformet Rødding Højskoles program, men skolens daglige ledelse overlod han til andre. Dens første forstander var den 33-årige teolog Johan Wegener, en broder til historikeren C.F.Wegener. Det var Johan Wegener, der med et mesterligt greb anslog folkehøjskolens historisk-poetiske grundakkord, da han indledede dens første akt i november 1844 med at citere optakten til Ingemanns »Valdemar den Store og hans Mænd «:

Stig op af graven, du slægt, som døde!

forkynd dit fald og afmal din brøde $!^{18}$ )

Men det kan ikke nægtes, at det højstemte greb savnede sangbund i de faktiske forhold. Wegener klagede vedblivende over elevernes råhed og materialisme, og han jamrede både over for Flor og Grundtvig over sine og skolens vanskelige kår. Til Grundtvig henvendte han sig »som til en fader og ven«, lidt opstyltet måske, men

15) C. Flor: Beretning om Folke-Høiskolen i Rødding, Kbh. I 846, s. I 3 .

16) Brev til Hans Nissen og L. Skau 8/9 I 843. Højskolens Ungdomstid I, nr. I3.

17) Den danske Litteratur i det nittende Aarhundredes første Halvdel, Kbh. I924, s. 205.

18) Johan Wegener: Tale ved Folkehøiskolens Indvielse i Rødding, Kbh. I845, s. 3 . 
havde Grundtvig ikke lovet på Skamling at stå skolen bi i starten? Det nævnte Wegener vel ikke, men det lå sikkert bag hans henvendelse. Endnu i november 1844, kun tre uger efter starten, bønfaldt han Grundtvig om dog at komme og besøge skolen: »Kom, vis os, hvorledes vi skal bære os ad; lær os at opdrage Deres nyfødte barn $\left.{ }^{19}\right)$ !« Men Grundtvig kom ikke.

Wegener var en ildfuld sjæl, men han savnede åbenbart den myndighed, den ligevægt og sejge udholdenhed, som til enhver tid kræves af en skoleleder og dobbelt her, hvor der var tale om en helt ny skoleform. Temmelig brat brød han op i foråret 1845, og Flor måtte nu for en tid selv bestride forstanderposten, indtil en egnet leder blev fundet.

En af dem, der var på tale, var den unge teolog Frederik Helweg. Han var født holstener, men grebet både af grundtvigianismen, den sønderjyske sag og den nordiske sag. I sommeren I 845 havde han på det nordiske studentermøde i ridehuset ved Christiansborg motiveret et leve for »den skandinaviske ånd i Finnernes land «; talen blev trykt i »Fædrelandet« og medførte sagsanlæg, da den øverste offentlige anklager, generalfiskalen, anså den for fornærmelig overfor Rusland! Mon Helweg ikke var den rette mand for Rødding? Han havde været på tale allerede ved nytårstid I845, og Flor har sikkert drøftet hans kandidatur med Grundtvig, da han i foråret 1846 besøgte ham i København og indbød Grundtvig til et otte- eller fjorten-dages sommerbesøg i Rødding. Da Flor ved skærsommertid skrev til Grundtvig om det planlagte besøg, lagde han dog ikke skjul på sin ængstelse for, om Helweg nu var dansk nok. Spørgsmålet er, skrev Flor, ikke blot det overfladiske: dansk eller tysk, »men om det åndelige, altså også hjertelige, livs sejr eller død her i Slesvig ... i grunden er det altså kun åndens liv jeg selv fægter for, idet jeg strider for danskheden og skandinavismen«. Flor foreslog, at Helweg kunne jo komme og prøve en tid sammen med ham ${ }^{20}$ ).

Grundtvig kom heller ikke denne gang til Rødding, skønt han ved samtalen med Flor i foråret havde stillet det i udsigt. Gennem professor J.F.Schouw, der var et fremtrædende medlem af skolens københavnske støttekreds »Syvstjernen«, lod Grundtvig Flor vide, at han slet ikke ville tale med Helweg om sagen, da han anså den

19) Højskolens Ungdomstid I, nr. 36.

20) Rosendal: Nogle Bidrag til Rødd. Højsk. s. 48, 5 I f. Højskolens Ungdomstid I, nr. 62. 


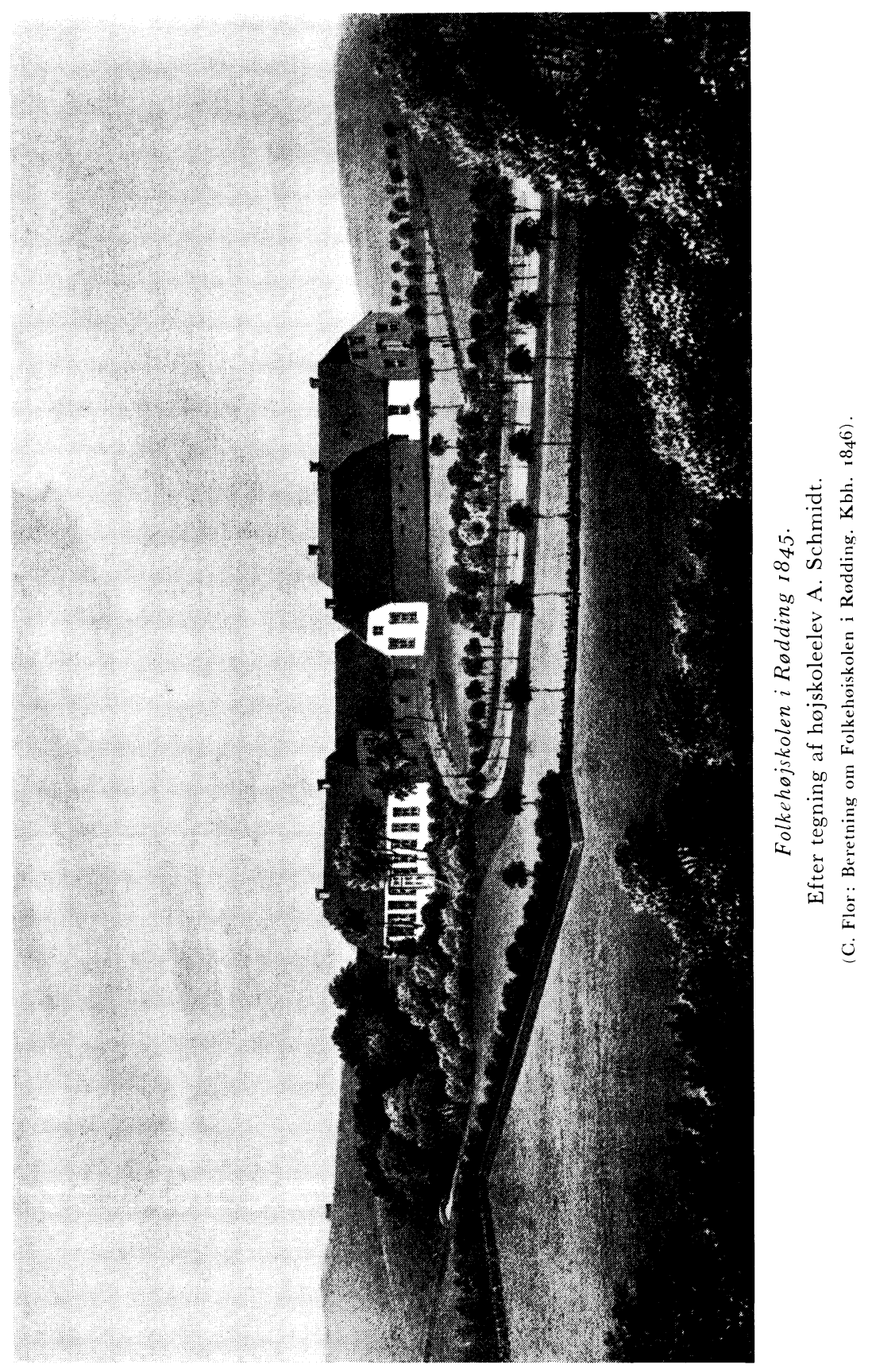




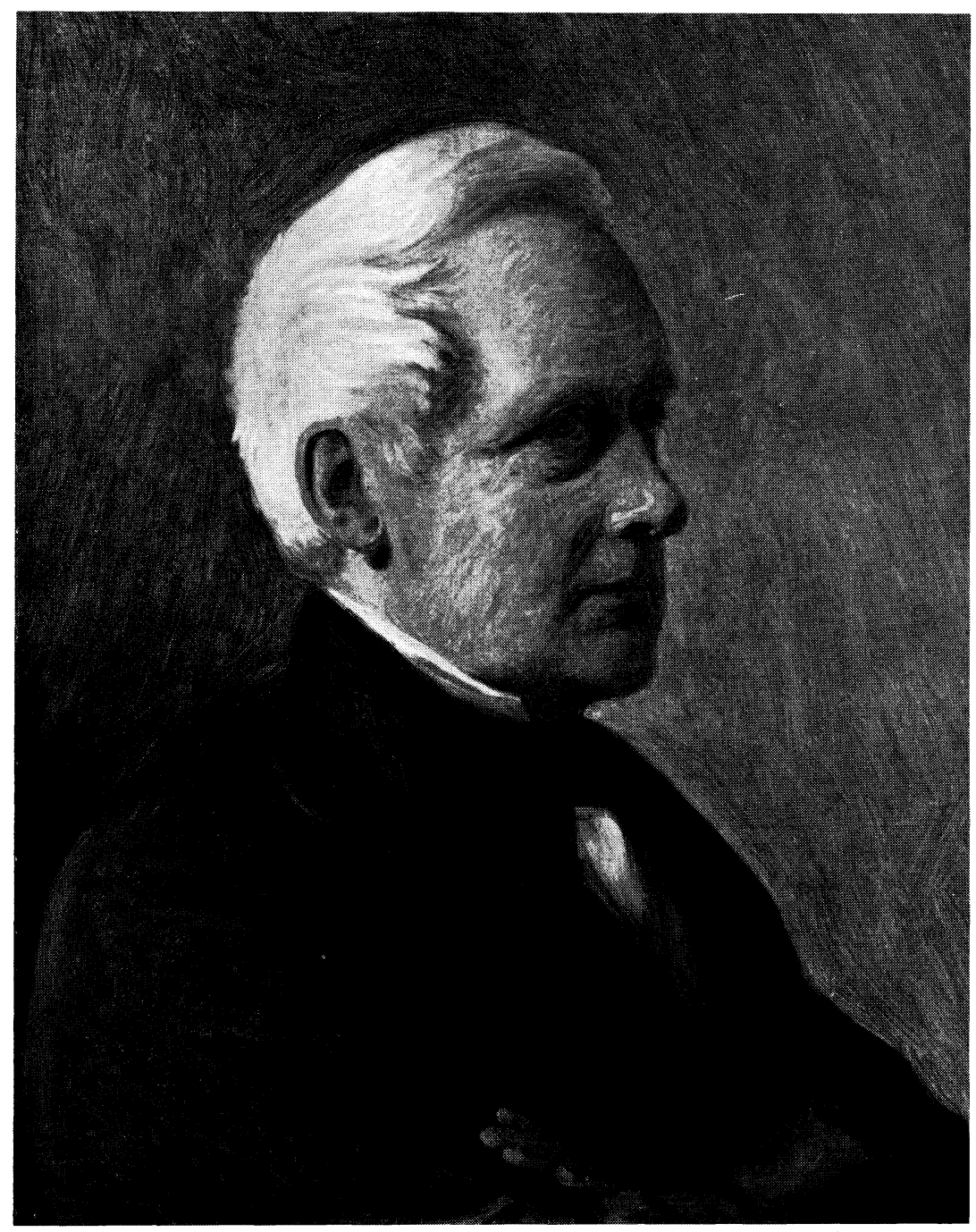

Chr. Flor.

Malet af Constantin Hansen, forstudie til »Den grundlovgivende Rigsforsamling«, ca. 1860

(Det nationalhistoriske Museum, Frederiksborg Slot). 
form, som Flor havde givet tilbudet, for fornærmelig. Schouw erklærede sig enig med Grundtvig og krævede et bestemt og ubetinget tilbud til Helweg om at blive eneforstander ${ }^{21}$ ). Flor tog hensyn til Grundtvigs og Schouws indvendinger, og da Schouw henvendte sig til Helweg, erklærede denne sig rede til at overtage forstanderposten fra efteråret 1846 ; Flor blev dog vinteren over på skolen.

I den korte periode, hvor Frederik Helweg prægede skolen - kort fordi den allerede i 1848 blev afbrudt af krigen - kom den historiskpoetiske linje til at træde stærkt frem. I en oversigt, som Helweg har givet over undervisningen $i$ halvåret $1846-47$, ligger hovedvægten på historien, litteraturen og mytologien, men der blev selvfølgelig også undervist i agerdyrkningskemi, fysik, plante- og husdyrlære. I aftentimerne brugte Helweg bl. a. Grundtvigs Krønikerim og ordsprogssamling, mens Flor fortolkede mytologien. Forøvrigt blev der også læst tysk med eleverne ${ }^{22}$ ).

Et tredje forsøg på at få Grundtvig til Rødding blev gjort af hans ven præsten Peter Rørdam i Mern. Han interesserede sig stærkt for skolen og havde allerede i I 845 skrevet til Grundtvig fra Sønderjylland, hvor han havde truffet Flor, at her »er Deres ideer om en bondeskole ... førte igennem, i deres begyndelse. ${ }^{23}$ ) I juni 1847 foreslog han Grundtvig, at de sammen skulle rejse til Rødding og »se, hvorledes det har sig med den skole, og hvad Helweg tager sig for «, men Grundtvig undslog sig med den mærkværdige begrundelse, at han ikke havde mod på det, »da jeg, Gud ske lov! befinder mig vel, er i arbejde og véd ikke, hvortil rejsen skulle nytte, eller hvem jeg skulle få til at besørge embedet i min fraværelse $\left.\ll^{24}\right)$. Så rejste Rørdam alene og fortalte bagefter Grundtvig om sit besøg. Han havde hørt landbrugslæreren tale om mejerivæsenet og Helweg om kristendommens indførelse hos Angelsakserne samt om Thors kamp med Hrungner, »og det var udmærket, så forståeligt og levende, fuldt af ordsprog «. Eleverne fulgte godt med, og indtrykket var fornøjeligt ${ }^{25}$ ).

Grundtvig har åbenbart fulgt skolen med fjern sympati. Kort efter nytår I 846 skrev han til Rørdam: »Vist nok ville vore bestræ-

21) Højskolens Ungdomstid I, nr. 63 .

22) Højskolens Ungdomstid I, nr. 66.

23) Peter Rørdam. Blade af hans Levnedsbog og Brevvexling, v. H. F. Rørdam, Kbh. I 892, II, s. 32 .

24) Peter Rørdam II, s. $64 \mathrm{f}$.

25) Peter Rørdam II, s. 69. 
belser for folkelig oplysning $i$ langden være så godt som frugtesløse, når den ikke fik en almindelig brændpunkt i en folkelig højskole; men bondeskolen i Rødding er en spådom, eller rettere et håndfået pant på spådommens opfyldelse i sin tid, og tiden er jo først, når folket begynder selv at føle trang dertil, så hvor vi blot kan vække og nære den, har vi forberedt hvad vi ønsker $\left.\ll^{26}\right)$.

Både ved denne lejlighed og senere, da han afviste Rørdams forslag om at tage med derned, slog Grundtvig fast, at det var tanken om en dansk højskole i Sorø, der betød noget for ham. Det var hans overbevisning, at Danmarks ve og vel beroede på, at den blev gennemført. Sammenlignet med drømmen om Sorøskolen var og blev den skole, der var skabt i Rødding, kun en biting.

\section{Sofus Høgsbro og Grundtvig.}

Da Rødding Højskole blev genåbnet efter treårskrigen, var Sorøplanen skrinlagt. Den havde været sin virkeliggørelse nær, så nær, at Christian VIII havde besluttet, at der skulle oprettes en kongelig realhøjskole på Sorø Akademi. Men efter statsomvæltningen i foråret $\mathrm{i} 848$ blev denne enevældige beslutning stillet $\mathrm{i}$ bero af de nationalliberale ministre, til Grundtvigs store fortrydelse. Til gengæld kom Rødding i gang igen, og der blev snart oprettet flere bondehøjskoler.

Frederik Helweg foretrak efter krigen præstegerningen i Haderslev, og Flor måtte igen ud med lygten for at finde en forstander til skolen. Det blev den unge Sofus Høgsbro, der fik opgaven. Han afbrød udsigten til en videnskabelig løbebane som historiker for at blive højskolemand. Flere, deriblandt Flor, havde opfordret ham til at blive præst i Slesvig, men han havde svaret, at han ville foretrække ansættelse ved en folkehøjskole. Når Flor var betænkelig ved det, skyldtes det, at Høgsbro ikke kunne synge - det var en slem mangel hos en højskolemand, mente Flor. Men da Flor derefter forhørte sig både hos H.N.Clausen og Grundtvig, og de begge anbefalede Høgsbro, kom Flor til det resultat, at når disse to mænd, der ellers aldrig var enige, pegede på den samme mand, måtte det være rigtigt at tage ham $^{27}$ ).

Sofus Høgsbro stod i modsætning til Flor og Helweg Grundtvig

26) Peter Rørdam II, s. 35 .

27) Rosendal: Nogle Bidrag til Rødd. Højsk., s. 63 f. 
personligt nær. Han var ganske vist 40 år yngre end Grundtvig, men hans lærer i Ribe Katedralskole Ludvig Chr. Müller havde åbnet hans øjne for Grundtvigs betydning, og som student havde han været en ivrig, men samtidig kritisk deltager i Danske Samfunds møder. Vartov gjorde derimod ikke særligt indtryk på ham. Det var gennem Grundtvigs sønner, at den personlige forbindelse kom i stand. Da Svend Grundtvig ville læse til student, bad han Høgsbro hjælpe sig med historie og geografi - den jævnaldrende Johan Grundtvig traf han på teologiske forelæsninger. Der opstod et varmt venskab mellem de tre unge mænd, og Høgsbro fik sin gang $\mathrm{i}$ Grundtvigs hjem og tog del i samtalen ved tebordet i Vimmelskaftet søndag aften og om sommeren på Bakkehuset. Høgsbro var en udpræget selvstændig natur, og han havde sikkert tit lyst til at modsige den gamle. Han bad gerne om nærmere forklaring, når Grundtvig udtalte sine uforgribelige meninger og tillod sig også at fremsætte tvivl, når Grundtvig f. eks. hævdede at solen gik rundt om jorden og påkaldte Josva og Tyge Brahe som autoriteter man måtte bøje sig for! Skønt Grundtvig aldeles savnede respekt for naturvidenskaberne, respekterede han afgjort den unge Høgsbro.

Høgsbro kunne også samstemme med Grundtvig - i hans folkelige anskuelser, $\mathrm{i}$ hans kærlighed til fædreland og frihed, $\mathrm{i}$ hans tillid til den menige danske mand. Denne samstemning voksede, da Høgsbro var kommet til Rødding. Herfra tog han jævnlig til København i skolens ærinde og i sine ferier; så boede han gerne hos sønnerne og besøgte tit Grundtvig ${ }^{28}$ ).

Høgsbros åbningstale på Rødding i november $185^{\circ}$ blev trykt i Grundtvigs tidsskrift »Danskeren«, hvor Grundtvig ellers skrev det meste selv. Grundtanken i Høgsbros tale var mere demokratisk end national, og hans ord virker den dag i dag aktuelle, når han understreger, at friheden ikke blot bringer goder, men også medfører forpligtelser. »Forhen var statsmagten lagt i embedsmændenes hænder; den enkelte borger og bonde kunne, og efter ønske skulle han endog, være ligegyldig for regeringens gang. Selv hvor den greb ind i hans egne forhold, skulle han med tavs ærefrygt bøje sig under dens vilje som den uimodsigelig ene rigtige. $\mathrm{Nu}$ skal derimod folket selv udtale sin vilje, og når den har fået kongens stadfæstelse, skal embedsstanden være dens udfører. Derfor kan folket da heller ikke længere

28) Sofus Høgsbro: Mit Forhold til Grundtvig, Tscherning og Monrad. Kbh. I902, s. $7 \mathrm{ff}$. 
gå hen i den gamle sorgløshed for alt, hvad der ikke angår deres eget hus og hjem. Til enhver især udgår det spørgsmål: efter hvilke grundsætninger vil du, at de fælles anliggender skal bestyres? Også på din stemme beror det, hvilke anskuelser og egenskaber de mænd skal have, til hvem de overdrages. Vil vi nu ikke nødes til at give os andre i vold, da er det ikke nok, at vi forstår os på det, som ligger os nærmest for hånden, det som er vort daglige kald ... men vi må tillige stræbe at lære vort fædreland og vore landsmænd at kende . . N Når vi således søger at erhverve os indsigt $i$, hvad der tjener til det heles tarv, og når vi har vilje og kraft til at gøre brug af denne indsigt, da vil vi ikke længer være døde, men levende lemmer på det store folkelegeme, da vil også vi give vort bidrag til, at folkeånden kan udvikle sin hele dybe ejendommelighed og opfylde det hverv, som i verdensudviklingen er den tildelt $\left.\ll^{29}\right)$.

Dette var en tale i grundtvigsk ånd, men uden al eftersnak. Det kunne have været en åbningstale for Sorøskolen. Høgsbro erklærede senere åbent, at den tanke, som lå til grund for Røddingskolen, var Grundtvigs Sorøtanke ${ }^{30}$ ).

\section{Striden om Rødding.}

Men hverdagen blev en anden. Høgsbro, der i mange henseender var en stejl, ja stridbar natur, havde ikke let ved at samarbejde med alle sine lærere. Ret hurtigt udvikledes et bittert modsætningsforhold til den af eleverne højt værdsatte landbrugs- og naturfagslærer $E d$ vard Thomsen. Striden hang utvivlsomt sammen med gemytternes uoverensstemmelse, men den havde også en principiel karakter: om skolen i første række skulle være en skole for borgerlivet - eller den skulle være en fagskole for vordende landmænd.

I denne strid fandt Høgsbro varm støtte hos Grundtvig. Da han i december 1852 var i København, talte han med H. N. Clausen og fik det indtryk, at han ønskede åndsfagene indskrænket - ville bønderne have en ordentlig dannelse for deres sønner, skulle de tage og sende dem til realskolerne! Fra Clausen gik Høgsbro lige til

29) Danskeren 14/12 1850, jfr. Arne Fog Pedersen: Danmarks første Højskole og dens Mænd, Kbh. 1944, s. $87 \mathrm{f}$.

30) Sofus Høgsbro: Beretning om Folkehøjskolen i Rødding 1850-53, Haderslev I 853, s. l. Jfr. Erik Appel: Sofus Høgsbro som aktiv højskolemand, Dansk Udsyn r 959 , s. $49 \mathrm{ff}$. 
Grundtvig og fortalte ham om samtalen. Grundtvig mente, at gik Clausens anskuelse igennem, var det ude med højskolen - og så talte han om oprettelsen af en højskole i Sjælland, Danmarks hjerte $\left.^{\mathbf{3 1}}\right)$ !

Det er ejendommeligt, at Grundtvig næsten altid, når Rødding kommer på tale, ender med at sige så omtrent: Forøvrigt mener jeg, at det er i Sorø skolen skal ligge! Hans nære ven, Peter Rørdam, var derimod så optaget af Rødding, at han i sommeren $185_{2}$ for tredje gang rejste til Sønderjylland for at besøge den. Han traf ikke Høgsbro hjemme, men hørte både på hans medlærer Gotfred Rode og på Thomsen og en anden naturfagslærer. Han var især betaget af Rodes sangtime: »Det var som var det Holger Danske selv, der sang for mig! « skrev han til sin kone. Alle karlene sang med ånd, syntes han, og de vidste, hvad de sang! Og herpå fulgte $\mathrm{i}$ brevet et suk over Grundtvigs passive holdning over for Rødding: »Det er underligt, at Grundtvig ej har været på den skole endnu, for det kan man mærke både hos lærere og ungdommen, at Grundtvig er til, og at han er en mægtig ånd, og at han elsker Danmark $\left.\ll^{\mathbf{3 2}}\right)$.

Hvad Vilhelm Andersen har sagt om Rødding i den Florske periode, kan også siges om Høgsbros : at skolen var højgrundtvigsk. Måske savnede skolen den stimulans, som den tyske fare betød i I 840erne og i86oerne - den omstændighed, at den var trængt tilbage i i 85 oerne, betød, at det nationale kit ikke var stærkt nok til at modstå indre brydninger. Dertil kom vel også, at Høgsbro var en noget kølig og tør lærer, mere historisk-prosaisk end historiskpoetisk anlagt. Rodes efterfølger fra $185^{2}$, den unge hedspore Jens Lassen Knudsen, fader til forfatteren Jakob Knudsen, bebrejdede ham jævnlig, at han ikke var grundtvigsk nok.

Men overfor Thomsen holdt Høgsbro og Knudsen sammen. Da striden tilspidsedes, fik de ved hjælp af skolens formand, præsten L. C. Hagen, lavet en ny ordning, hvorefter bestyrelsen skulle udpeges af tre tillidsmænd. I I855 afgav den forening, der stod bag skolen fra dens start, sin magt til disse tillidsmænd, og Flor, der skulle være den ene af dem, fik den opgave at gå til H. N. Clausen og Grundtvig og bede dem blive de to andre. Det gik ikke så godt. Grundtvig ville nok, men Clausen vægrede sig ved at sidde i komité med Grundtvig, der jo aldrig ville give efter i sine anskuelser

31) Høgsbros dagbog $3 / 12$ I852, trykt i Højskolens Ungdomstid, I, nr. I Io.

32) Peter Rørdam II, s. 222 f. 
eller påstande. Da Flor fortalte Grundtvig, hvad Clausen havde sagt, sagde Grundtvig, at Clausen burde skamme sig ved ikke at ville gå med ham i en god $\mathrm{sag}^{33}$ ). I det eneste brev, der er bevaret fra Grundtvig til Rødding, skrev han: »Vistnok er jeg kun lidet skikket til at gavne højskolen uden ved måske at kunne afvende dens skade, men dette anser jeg efter omstændighederne vigtigt nok, så jeg ikke bortskyder den mig viste tillid $\ll^{34}$ ).

Men Rødding var en hvepserede i de dage, og da Flor holdt hånden over Thomsen, kom det snart til sammenstød mellem Grundtvig og Flor. Overfor Hagen udtrykte Flor sin bedrøvelse over, at han skulle komme i modsætningsforhold til Grundtvig, »hvis dom jeg plejer at lytte til som ingen andens, og som jeg så ofte med taknemmelighed har kaldt - og, trods denne sag og dens mulige følger, skal vedblive at kalde min åndelige mester og herre $\ll^{35}$ ).

$\mathrm{Da}$ en af skolens venner, folketingsmand Niels Andersen Hansen, ved samme tid drøftede vanskelighederne i Rødding med Grundtvig, trøstede den gamle ham med, at skolen nok skulle holde pinen ud, da den havde overstået krigen, og »uden kamp ingen $\left.\operatorname{sejr} \ll^{36}\right)$.

For øvrigt nænnede Grundtvig ikke at holde Flor udenfor. Den eneste gang, han benyttede sin stilling som skolens tillidsmand til at gribe ind i Rødding Højskoles forhold, var da han i foråret 1856 sammen med de andre tillidsmænd, Hans Krüger og J. L. Knudsens broder Knud L. Knudsen, foreslog at Flor og Helweg, begge Thomsens beskyttere, skulle indtræde $\mathrm{i}$ bestyrelsen ${ }^{37}$ ). I denne situation opsagde Høgsbro sin stilling, men ingen turde slippe ham, og Flor måtte $\mathrm{i}$ hast skaffe Thomsen et nyt og bedre levebrød. Han havde været en dygtig lærer, men det var den eneste udvej til at få ende på striden.

Striden hørte dog ikke op, fordi Thomsen flyttede fra Rødding. $\mathrm{Nu}$ kom J. L. Knudsen og forlangte, at skolen skulle tone rent flag som grundtvigsk skole. I efteråret ${ }^{8}{ }_{5} 6$ noterede Høgsbro i sin dagbog: »Talte meget med Knudsen om hans mening, at denne skole

33) Flor til Hagen 22/6 I 855, Højskolens Ungdomstid I, nr. r6o.

34) Grundtvig til Hagen 17/1 I 856, Højskolens Ungdomstid I, nr. I 78.

35) Rosendal: Nogle Bidrag til Rødd. Højsk. s. 86. Jfr. Højskolens Ungdomstid I, nr. I 79 .

36) Højskolens Ungdomstid I, nr. I80.

37) Højskolens Ungdomstid I, nr. 187. Jfr. Høgsbros Beretning om R. H. I8596o, s. 23. 
burde være bestemt grundtvigsk, så den stødte alt andet bort, hvilket jeg ikke kunne gå ind på $\left.\ll^{38}\right)$.

De to opfattelser, Knudsens og Høgsbros, står klarest over for hinanden i en brevveksling fra I86o. Her spurgte Knudsen Høgsbro: »har du dog ikke endnu erfaret, ja oplevet det, at vor kærlighed til, vor delagtighed i folkelivet: det at vi drives og opvarmes og oplyses af Folkeånden - det er det, som sætter os i stand til at tiltale folket og åbne de unges øje for Danskens og Danmarks »frugtbare herlighed «! Og Knudsen gik videre endda: Han sagde til Høgsbro, at det var hans grundskade, at han ikke tror, »at den evige sandhed har i Jesus Kristus klædt sig i ordet, som det endnu lever på syndige menneskers tunge. Thi her ligger din grundskade; fra denne tvivl stammer al din halten og dit forhold til den danske sandhed, til Danmarks Folkeånd, som om han var en skygge ...«

Sagtmodigt svarede Høgsbro: »Vi skal ikke alle være bjergbrydere som Grundtvig, vi skal tværtimod stræbe at gøre det ædle metal, han har brudt, til gangbar mønt, selv om det derfor bliver nødvendigt at give det en tilsætning af kobber. På anden måde kan det ikke blive folkets ejendom $\left.\ll^{39}\right)$.

De to opfattelser, der tørner sammen her, støder man gang på gang på i den danske højskoles senere historie. Man kunne sige, at den ene, Høgsbros, repræsenterede Sorø-linjen, - den anden, Knudsens, Vartov-linjen, og at det var svært at forene dem begge - det var der ingen af Rødding-lærerne, der hidtil havde formået. Også her var der dog tale om forskellige gemytter, og man kommer ikke uden om, at der var noget umodent og begrænset i Knudsens krav om at tone rent flag.

\section{Ludvig Schrøders svendetid på Rødding.}

Det er dog et bevis på højskoletankens indre styrke, at Rødding Højskole overlevede »de puniske krige« i I 850 erne $^{40}$ ) - den ikke blot overlevede, men gik snarest styrket ud af krisen. Men først måtte også Høgsbro slippe roret. I I 858 havde han sagt ja til at

38) Høgsbros dagbog 19/9 1856, Højskolens Ungdomstid I, nr. 194.

${ }^{39}$ ) Sofus Høgsbro: Brevveksling og Dagbøger, v. Hans Lund, I, I923, s. $47 \mathrm{f} \mathrm{-}$ Jfr. Erik Appel: Sofus Høgsbro som aktiv højskolemand, Dansk Udsyn I959, s. 55 .

40) Udtrykket brugt af Thomsen i et Brev til Høgsbro, Højskolens Ungdomstid I, nr. 222. 
lade sig vælge til folketingsmand $\mathrm{i}$ de kongerigske enklaver $\mathrm{i}$ Sønderjylland, og på rigsdagen vandt han hurtigt en førerstilling blandt de grundtvigske venstrebønder. Men jo stærkere hans stilling fæstnedes på Christiansborg, des mere kom han og hans skole i vinden i den nationalliberale presse, $\gg$ Dagbladet $\ll$ og $\gg$ Dannevirke Det kom også til at gå ud over statstilskuddet til skolen; kultusminister Monrad mente ikke, at højskolegerning og politisk indsats kunne forenes. I foråret I86 I måtte Høgsbro skrive til Flor om skolen, at »det var vist ønskeligt, at De i tide tænkte på en eller anden udvej til at sikre dens åndelige liv « ${ }^{41}$ ).

Den mand, der kom til at sikre skolens fortsatte »åndelige liv«, var den unge teologiske kandidat Ludvig Schrøder. I efteråret I86 I skrev Høgsbro fra København til sin kone og Knudsen, at han havde bedt Schrøder komme til Rødding for at vikariere for sig, og han tilføjede, at det var både Schrøders og hans tanke, »at han ad åre, om denne prøve går vel, som den vistnok vil, skal indtage enten min eller Knudsens plads $\left.\ll^{42}\right)$. - Det vides ikke, hvorledes Høgsbro havde fået øje på Schrøder, men den teologiske vennekreds »Lille Theologicum«, som Schrøder var med i, var den foregående vinter kommet i Grundtvigs hjem, hvor også Høgsbro var stadig gæst. Her havde Grundtvig meddelt de unge sine tanker om Gudsordets vandring fra folk til folk gennem tiderne, de forelæsninger, som siden blev udgivet under navnet »Kirke-Speil«. Det skyldes Grundtvigs inspiration, at den ene efter den anden af de unge akademikere fra »Lille Theologicum《 besluttede at gå ind i folkehøjskolen. Først Schrøder, siden Ernst Trier, Jens Nørregård og Christopher Bågø. Den unge Schrøder var lige opfyldt af Grundtvigs folkelige og kirkelige budskab. Søndag efter søndag gik han til gudstjeneste i Vartov, og han fordybede sig i Grundtvigs skrifter. I et foredrag han $\mathrm{i}$ foråret $\mathrm{I} 86 \mathrm{I}$ holdt $\mathrm{i}$ det grundtvigsk-prægede »Danske Samfund «, talte han om Nornegæst som billede på Nordens kæmpeånd, der »skal hæves op på højsædet, og det bliver han, når hele folket tager ham i favn og gør ham og hans modersmål til højskolens ånd og mål $\left.\ll^{43}\right)$.

Det var altså en helhjertet grundtvig-discipel, der nu kom til Rødding. Han var der kun i seks uger, men gennem de breve,

41) Højskolens Ungdomstid I, nr. 267.

42) Højskolens Ungdomstid I, nr. 282.

43) Frederik Schrøder: Ludvig Schrøders Liv og Gerning I, Kbh. I935, s. I 2 I f. 


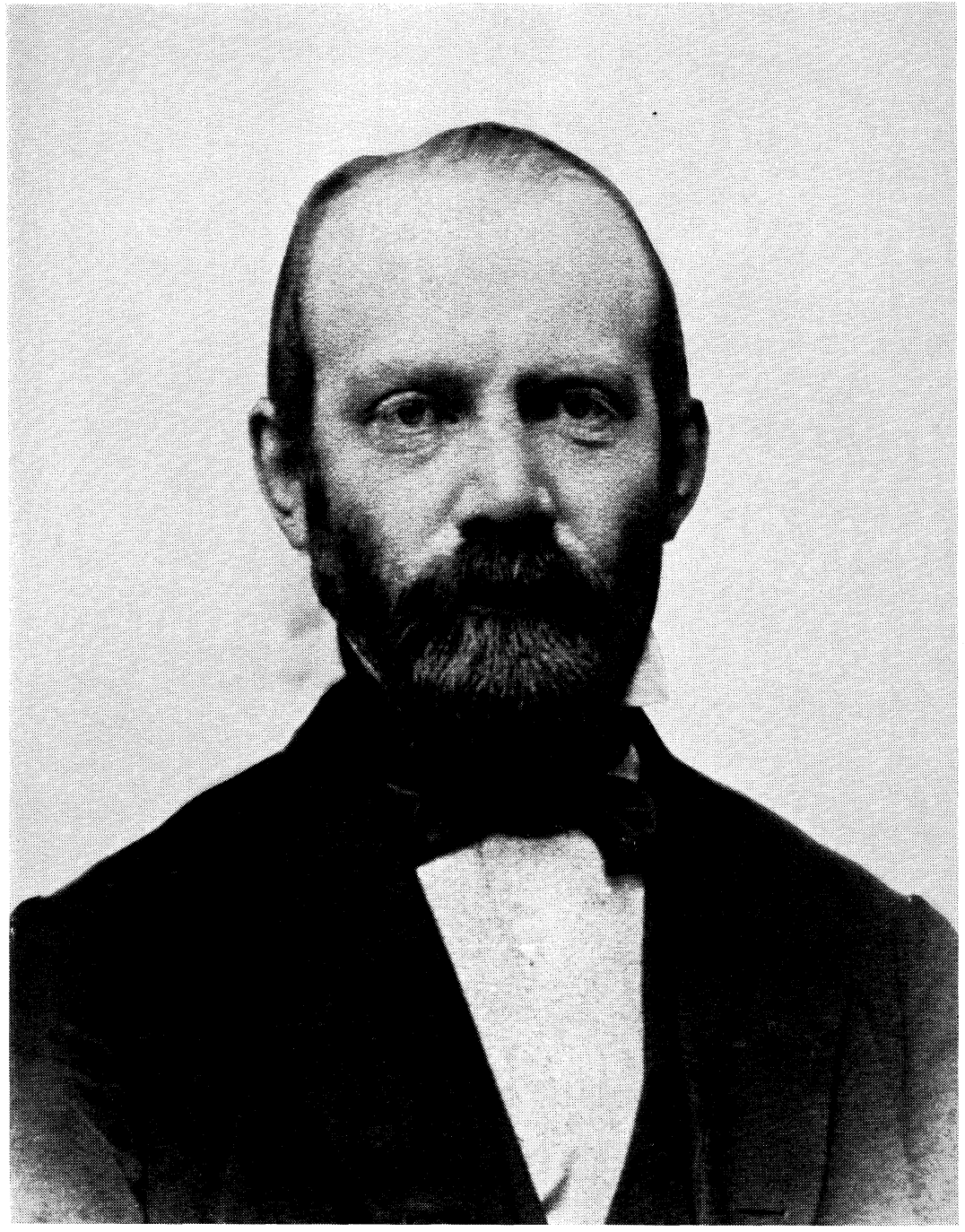

Sofus Høgsbro.

Fotografi fra begyndelsen af i 860'erne. 


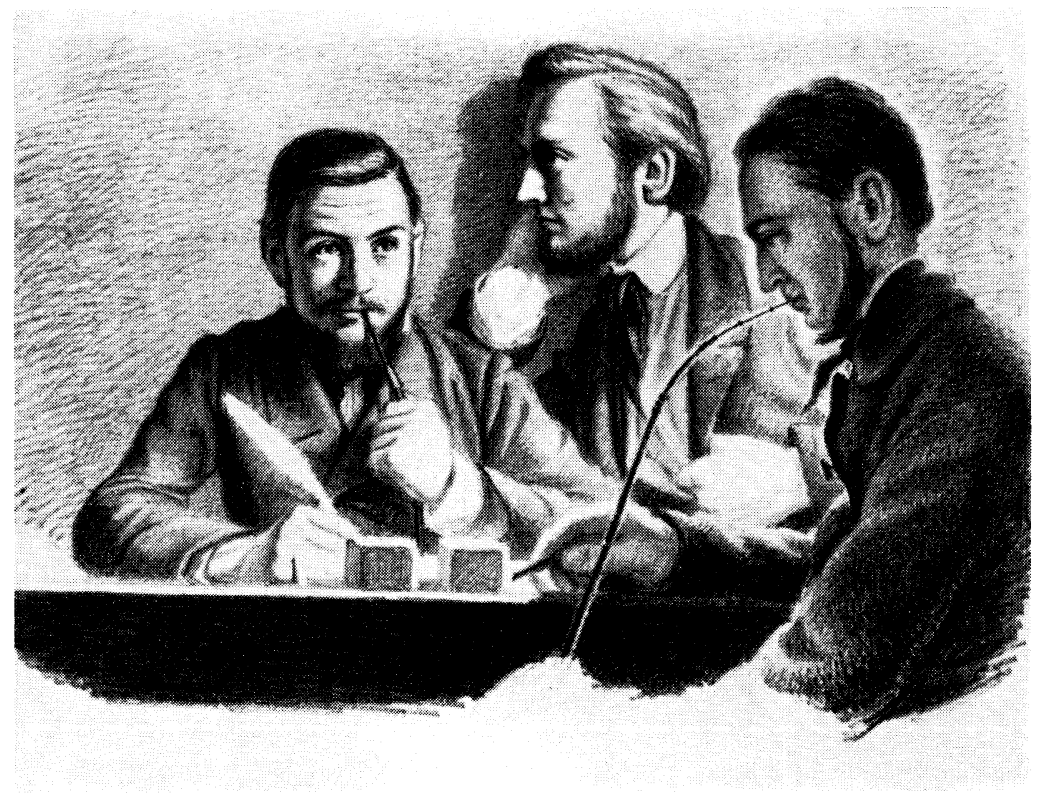

Ludvig Schroder og to af hans venner.

Portrætstudie af H. Dirckinck Holmfeld til »Lille Theologicum«. - Schrøder leder mødet med pennen i hånden, til højre for ham Christopher Bågø og Jens Paludan-Müller.

(Det kongelige Bibliotek). 
han sendte sin kæreste Charlotte Wagner i København, mærker man hans indvielse $\mathrm{i}$ opgaven. Han mødte op med al sin grundtvigske ballast, og det har sikkert været strengt for eleverne til at begynde med! I et af sine breve fortæller han, at han aftenen før var begyndt at læse Grundtvigs »Optrin af Kæmpelivets Undergang i Nord« højt for eleverne i spisesalen, »men jeg fortalte ikke sagaen først, og så faldt det folk for svært. Da Knudsen sagde mig det, blev jeg forknyt, men han trøstede mig med, at eleverne var så glade ved mig $\mathrm{i}$ det hele, så det skulle intet gøre $\ll^{44}$ ).

Ved en anden lejlighed fortalte Schrøder om Odysseus og Penelope som billede på folkeånden og folkehjertet, men han tilføjer redeligt $\mathrm{i}$ referatet til sin kæreste, at eleverne »endnu hører lidt vantro på disse tydninger $\ll^{45}$ ). Det kan man måske ikke fortænke dem i! Schrøder var endnu som et ekko af Grundtvigs dybe røst, vidt forskellig fra den kritiske Sofus Høgsbro. Men han var fyldt af ægte begejstring, og de indtryk, han modtog, forstod han efterhånden også at bearbejde. Til at begynde med lod han sig helt bjergtage af Jens Lassen Knudsens syn på skolen. Til sin broder Johannes skrev han efter et par ugers ophold på skolen: »Eleverne ved ikke, om de her skal uddannes til landmænd, altså til forvaltere, eller de skal søge en dansk dannelse, tjenlig til at vække dem til et friskt åndeligt liv. Skolens bestyrelse tilsigter begge dele og har taget lærere derefter. Men det går ikke i længden $\left.\ll^{46}\right)$. Knudsen stod selv i begreb med at rejse til Christen Kold på Fyn, hvis højskole han anså for idealet. Han skrev til Kold: »Når Høgsbro og jeg går bort . . . lad så »vore folk« prøve en dyst med jætterne : Om Rødding mest skal ligne Asgård eller Udgård!« Han vedblev at tilskynde Schrøder til at tage med ham på besøg hos Kold »for at se den skole, som Grundtvig selv kalder den mest folkelige ${ }^{47}$ ). I anden forbindelse klagede Knudsen over Grundtvigs ligegyldighed for Rødding og over at Flors magt derved øgedes. For Knudsen at se havde Flor i den grad »blandet sandt og falskt, skin og virkelighed, jævnhed og opskruethed sammen, at den sidste trevl af de hid-

44) Højskolens Ungdomstid II, Rødding nr. 297.

45) Højskolens Ungdomstid II, Rødding nr. 304.

46) Højskolens Ungdomstid II, Rødding nr. 295.

47) Højskolens Ungdomstid II, Rødding nr. 303. Der må sigtes til en privat ytring af Grundtvig. Offentligt slog han først til lyd for Kolds Højskole ved vennemødet i København 1865 . 
tidige rødder må overskæres, om det skal blive til noget« med Rødding $\left.{ }^{48}\right)$.

Således bearbejdet af Knudsen vendte Schrøder ved juletid I 86 I tilbage til hovedstaden, »så fuld af nye tanker, som et træ i de varme egne af aber med snohaler, som hoppe fra gren til gren; så fuld, at selv gamle Grundtvig er halv ræd for, det går ikke endnu an at prøve på at føre dem ud i livet $\left.{ }^{48 a}\right)$.

Da Schrøder i København traf Høgsbro, lod han straks kritiken gå videre til ham. Og Høgsbro refererede det videre til Flor, der skuffet udbrød: »Så kan vi jo heller ikke bruge ham《! Det var synd, for - som Høgsbro udtrykte det - »Schrøder har været afholdt af alle elever og synes at være $i$ besiddelse af alle ønskelige egenskaber, den énsidige grundtvigianisme fraregnet«. En grundtvigianisme, der gik over gevind som Knudsens, ville hverken Flor eller Høgsbro vide af. De prøvede andre muligheder, bl. andre Gotfred Rode, der havde vist sig så velegnet $\mathrm{i}$ begyndelsen af $\mathrm{i} 85$ oerne, men alt glippede $^{49}$ ).

Schrøder ønskede imidlertid at komme til Rødding, og han havde da også fået Knudsen lidt på afstand. Høgsbro havde opsagt sin stilling til efteråret, og afgørelsen af, hvem der skulle være hans efterfølger, kunne ikke udskydes længere. I februar I862 skulle Schrøder holde et foredrag om Rødding Højskole i »Danske Samfund «. Flor blev gjort opmærksom derpå og kom til stede. Den tale, Schrøder her holdt, var ikke énsidig. Han sagde, at skolen måtte gå i tre retninger: Den måtte gennem modersmålet og fædrelandshistorien vække den folkelige bevidsthed - den måtte opfostre dygtige borgere ved en beskrivelse af fædrelandets naturlige og borgerlige forhold - og den måtte lette muligheden for bonden til at blive dygtig i sin gerning. - Det var vel talt, syntes Flor, han rejste sig og sagde, at dette var som talt ud af hans hjerte ${ }^{50}$ ), og Høgsbro, der havde følt sig ilde til mode ved Schrøders kritik, fandt det nu også forsvarligt at overlade styret til Schrøder. Han skrev til Flor, at det gav udsigt til opløsning af disharmonien i en god melodi. Det gamle Rødding ville jo rigtignok gå i stykker, men om en énsidig

48) Højskolens Ungdomstid II, Rødding nr. 307, og I, nr. 264 (brev til P. K. Algreen I 86 I).

${ }^{48}$ ) Brev fra Ludvig Wagner til Olaus Arvesen 3/1 1862 (Universitetsbiblioteket, Oslo).

49) Højskolens Ungdomstid II, Rødding nr. 306.

50) Frederik Schrøder: Ludvig Schrøder I, s. I $39 \mathrm{f}$. 
udvikling ville der dog ikke blive tale, »og den kedelige strid om herredømmet her, som kun gør skade, ville høre op $\left.\ll^{51}\right)$.

\section{Ludvig Schrøders ledelse af Rødding.}

I virkeligheden var Schrøder ikke en énsidig natur, men modtagelig for åndelig påvirkning fra mere end een side. Dog var det, som han ved nytårstid 1862 skrev til sin gamle rektor, Chr. Listov, »tilliden til, at Grundtvig havde det rette øje for nødvendigheden og beskaffenheden af den danske folkelige oplysning «, som havde givet ham mod til at rejse til Rødding i efteråret. Han var her under samværet med J.L.Knudsen, den nye grundtvigske præst Hans Sveistrup og de af eleverne, der havde åndelig sans, blevet styrket $\mathrm{i}$ »lysten til at virke for, at den danske almues hjerter kan brænde for det store mål, Nordboerne have, og som fædrene varslede om $\left.\ll^{52}\right)$.

Men nu havde Schrøder altså fundet nåde også for Flors og Høgsbros øjne. I foråret 1862 blev det aftalt, at Schrøder skulle være forstander og til medlærere have teologen Heinrich Nutzhorn, en af hans nærmeste venner, og veterinæren Rasmus Fenger, der vel var af ædel grundtvigsk æt - søn af præsten P.A. Fenger - men også gammel Røddingelev af Edvard Thomsens skole.

Man mærker Flors diplomatiske spil i denne sammenhæng, men kombinationen viste sig lykkelig, og samarbejdet mellem de tre nye lærere blev så inderligt, at de efter krigen I 864 kunne fortsætte det i Askov.

På en måde kunne man have ventet, at Grundtvig ville vise særlig deltagelse som tillidsmand for en skole under Schrøders ledelse. Men tillidsmandsposten krævede kun indsats ved bestyrelsesskifte, og tøjlerne lå her nu igen fast $\mathrm{i}$ Flors hånd. Grundtvigs deltagelse kom til at indskrænke sig til gode ønsker: Da de unge under Schrøders ledelse hyldede ham på hans fødselsdag i september 1862, svarede den gamle med at udtrykke ønsket om, at han - Schrøder - kunne bidrage til at fortsætte det folkelige røre, som var begyndt dernede i Sønderjylland $\left.{ }^{53}\right)$.

Nok så meget betød det nu for Schrøder, at han havde mødt

51) Højskolens Ungdomstid II, Rødding nr. 3 I6.

${ }^{52}$ ) Højskolens Ungdomstid II, Rødding nr. 308.

53) Højskolens Ungdomstid II, Rødding nr. 334 . 
Kold. Han var ganske vist blevet introduceret af J. L. Knudsen, men der er ingen tvivl om, at det besøg han sammen med Nutzhorn og Knudsen aflagde hos Kold i foråret 1862 , gjorde dybt indtryk på ham. I et brev til broderen skildrer han Kold »som en slags Sokrates«, der siddende i sin stol taler med de mange bønder og bønderpiger, som kommer langvejsfra for at gæste skolen - og taler sådan, at han vækker noget hos dem; »han er rig på livserfaring og på fortællinger, og med disse skatte beriger han sine tilhørere, idet han navnlig lægger an på at fremme virkelysten hos $\left.\operatorname{dem} \ll^{54}\right)$. I dette billede har Schrøder ikke blot givet et portræt af Kold, men også af sig selv; det hos Kold, Schrøder havde brug for, var den fremstilling, der kunne ægge virkelysten. Men den sammenhæng mellem folkelig livsoplysning og kristelig vækkelse, som Schrøder mødte hos Kold, hos Knudsen, hos Sveistrup og stærkt betagende hos lægprædikanten Peter Larsen Skrappenborg, den blev et karakteristisk nyt træk i Rødding Højskoles ansigt i Schrøders tid. Da Cornelius Appel efter I 864 optog en højskolegerning i Rødding, blev Vartovlinjen og ikke Sorø-linjen skolens spor.

Men i Schrøders tid kunne alt dette endnu godt forenes med Flors linje. Den alt andet end loyale indføring, som J. L. Knudsen havde givet Schrøder i Rødding-forholdene, havde indeholdt et vrængbillede af Flor. Det kom nu til et nært og livslangt samarbejde mellem Schrøder og Flor. De kunne mødes i dyb forståelse af Grundtvigs folkelige tanker og i fælles national og politisk målsætning. Schrøder holdt, bedre end tidligere Høgsbro, Flor nøje underrettet om alt, hvad der foregik på skolen, og mødte oprigtig påskønnelse af den evne, som han og hans hustru havde til at skabe et harmonisk forhold ikke blot inden for lærer- og elevkredsen, men også til at komme i nær kontakt med egnens befolkning. Det belønnedes ved, at omegnens bønder i stort tal uden vederlag kørte tømmer og tegl til Rødding, da skolens nye lade og gymnastik- og forsamlingssal skulle bygges i sommeren i863. Det var denne nære samhørighed mellem skole og egn, der gav Røddingmilieuet navnet »det ideelle hjørne« $\mathrm{i}$ fremmedherredømmets tid.

Ved et offentligt møde i foråret ${ }_{1} 86_{3}$ talte Schrøder om Rødding Højskoles historie i sammenhæng med hele det danske folks historie. »Det er den danske folkeånd og borgerlige oplysning, som var al-

54) Højskolens Ungdomstid II, Rødding nr. 322. 
mindelig i gamle dage hos almuen, der selv deltog i landets styrelse, men som blev trængt tilbage fra Knud den Helliges tid af, som nu skal genopvækkes og fremmes, da folket atter er kaldet til en livlig deltagelse $\mathrm{i}$ rådslagningen om det fælles vel, en almindelig opgave, som får sin særegne karakter ved Rødding Skoles forhold til den slesvigske sag og næsten samtlige elevers fremtidsbestemmelse som agerdyrkere $\ll^{55}$ ). Ved samme møde talte Nutzhorn om nogle ordsprog og naturfagslæreren Wiinstedt om dampens betydning. For Schrøder bestod der både nu og senere en sammenhæng mellem folkelig oplysning og erhvervslivets fremme - det var ikke tilfældigt, at han senere på Askov tog ivrigt del i Hedeselskabets indsats og gjorde »Danmarks hjælpekilder og næringsveje« til hovedemne for sine foredrag.

Men næppe havde Rødding Højskole for første gang i sin bevægede historie fundet et roligt leje for kræfternes elv, før dens virksomhed blev brat standset af krigen i 864 .

Da dens lærere efter krigen besluttede at rykke teltpælene op og flytte til Askov nord for Kongeåen for $\mathrm{i}$ frihed at kunne fortsætte deres folkelige oplysningsgerning, støttede Flor Røddings arvtager så varmt, at Schrøder gav Askov Højskole navnet »Flors Højskole«. Den højskole, der var begyndt i Rødding, fik i Schrøders tid uden at fornægte sin arv et så stærkt grundtvigsk præg, at den blev midtpunktet for den grundtvigsk-prægede højskole i Danmark. Den forstod - for at vende tilbage til Høgsbros svar til Jens Lassen Knudsen i I86o - at gøre det ædle metal, som Grundtvig havde brudt, til gangbar mønt, uden at slække væsentligt på værdien.

Rødding Højskole var ikke den eneste højskole, der fik betydning i tiden før I 864. Både Kold og N. J. Jensen, der prægede Hindholm Højskole stærkt i tiden før I 864, vedkendte sig discipelforhold til Grundtvig, og på Grundtvigs egen højskole, Marielyst ved København, fik den gamle omsider sin egen højskoletalerstol, selv om han kun benyttede den ved sjældne lejligheder ${ }^{56}$ ).

Grundtvigs forhold til den danske folkehøjskole blev aldrig så nært som dens til ham. Drømmen om den store danske folkelige højskole i hjertet af Sjælland vendte han gang på gang tilbage til, og det var ham nok en sorg, at den lille på Marielyst ikke havde

55) Schrøder til Flor, Højskolens Ungdomstid II, Rødding nr. 355.

56) N. F. S. Grundtvig: Taler paa Marielyst Højskole I856-7I, udg. af Steen Johansen, Kbh. I956. 
betingelser for at følge Sorø-linjen. Hvad Rødding angik, lå den altfor langt borte. Men i en af sine sidste taler på Marielyst, i efteråret r866, dvælede den gamle dog med glæde ved de mange nye bondehøjskoler, der nu var opstået, og over al den gode fornøjelse, de beredte de unge. Her tænkte han vel ikke mindst på de skoler, som var skabt af det kuld, der i vinteren I860-6 I havde lyttet til hans tale. 